\title{
White rust species (Chromista, Peronosporomycetes, Albuginales, Albuginaceae) on common weeds in Hungary
}

\author{
Tamás Tóth - György János Kövics \\ University of Debrecen, Plant Protection Institute, Debrecen, Hungary
}

\begin{abstract}
SUMMARY
The obligate plant parasite fungi in the family Albuginaceae are responsible for causing white rust diseases on weeds and they are rather common worldwide. Weedy plants with characteristic symptoms have been collected in 2014 and 2015 on location Hajdú-Bihar and Jász-Nagykun-Szolnok counties in Hungary. The determination of the species were based on the morphological characters both pathogens and hosts. Albugo candida was determined on shepherd's purse (Capsella bursa-pastoris). Common purslane (Portulaca oleracea) is a host for Wilsoniana portulacae. The fungus Wilsonia bliti (syn.: Albugo bliti), the causal agent of white rust disease was found on redroot pigweed (Amaranthus retroflexus).
\end{abstract}

Keywords: white rust diseases, Albugo candida, Wilsoniana portulacae, Wilsoniana bliti, Albugo bliti

\section{INTRODUCTION}

The member of Albuginales fungus order are obligate biotrophic plant pathogens. White rust or white blister diseases caused by the members of the Albuginaceae family has been reported from a great variety of hosts.

Albugo candida was the first described species in the Albuginaceae under the name of Aecidium candidum Persoon (Gmelin, 1792), then it was transferred to Uredo (Persoon, 1801), finally it was replaced to its own genus, Albugo (de Roussel, 1806). The fungus Albugo candida has more than 400 host species, including cultivated plants from the family Brassicaceae like horseradish (Armoracia rusticana) wide ranging at HajdúBihar County in East Hungary.

The next step was Wilson's findings in 1907, who listed 13 species of Albugo, but most of them was host- or at least plant-family specific.

More than a century after de Roussel's discovery, Biga (1955) recognized 40 species of Albugo which were almost impossible to differentiate base only on conidial morphology. This monogenic state of the Albuginaceae only changed when Thines and Spring (2005) made their revision. They used the ultrastucture of the sporangia observed in SEM (Scanning Electron Microscope) to identify the major lineages of the family Albuginaceae.

The newly introduced Wilsoniana genus contains some white rust pathogens, which are parasitic to the members of the Caryophyllales plant family. The two genera, Albugo and Wilsoniana can be differentiate on the base of sporangial ornamentation only. The sporangia of Wilsoniana are mostly broadly pyriform. The sporangium has a slight crescent moon-like wall thickening which covering large part of the lateral walls and this formation is the most prominent above the equator of the sporangia. The fertilization in Wilsoniana and Albugo differ also largely from each other (Davis, 1904).

The species of Wilsoniana have little economic importance because they infect harm weedy plants mostly.

\section{MATERIALS AND METHODS}

The weed plants were collected in 2014 and 2015 years on four locations (Debrecen, Szolnok, Kunszentmárton, Kisújszállás) in Hajdú-Bihar and Jász-Nagykun-Szolnok county (Middle and East Hungary) with characteristic white rust symptoms. The weed species were observed in maize and sunflower fields, next to roadsides and river banks. The samples were collected during the vegetation period, mostly in summer time. Collection were made mostly from leaves but in case of Albugo candida from stems, floral stems and inflorescences too.

Multiple plants were collected from each weed species, víz. shepherd's purse (Capsella bursa-pastoris /L./ Medik.), common purslane (Portulaca oleracea L.) and redroot pigweed (Amaranthus retroflexus L.).

The morphological characteristics of the pathogens were examined by preparing freshly collected materials and observed them under light microscope. When host tissue contained sexual spores (oospores) they were cautiously compressed with a scalpel. Asexual spores (sporangiospores) and sexual spores (oospores) measurement were taken by using a Canon PowerShot A520 digital camera and ImageJ software. The identification based on host plant and morphology of pathogen. To assure the appropiate values the results were cross-checked with the descriptions of Choi and Priest (1995). 25 reproductive structures were measured per samples. 


\section{RESULTS AND DISCUSSION}

\section{Albugo candida (Pers.) Roussel on shepherd's purse (Capsella bursa-pastoris /L./ Medik.)}

According to Systematic Mycology and Microbiology Laboratory Fungal Database (Farr and Rossman, 2015) Albugo candida was recorded on more than 400 host plants. This is a common pathogen especially on shepherd's purse (Capsella bursa-pastoris) and throughout its vegetation period in almost any larger population the white rust symptoms on the leaves or stems are observable (Choi et al., 2007). In Hungary the disease caused by this pathogen is not so serious, but near horseradish (Armoracia rusticana) plantations (cultivated host of the pathogen) it could be harmful. There are two kinds of infection in case of Capsella bursa-pastoris, the first one is the local infection when only the white to cream-coloured pustules can be observed on leaves, stems, floral stems and inflorescences. The second one is systemic infection when swollen, malformed and sterile flower arose so the result of the infection is abnormal growth (Figure 1/A, 1/C).

In the collected plants the pustules were approximately between 1 to $3 \mathrm{~mm}$ in diameter (Figure 1/B). These blister-like lesions contains the asexual spores (sporangiospores). Under the microscope it was clearly visible that these hyaline sporangiospores produced in chains, mostly vacuolate, nearly spherical and their average size were 15.2 x $14.4 \mu \mathrm{m}$ (Figure 1/D). Oospores could not be observed.

Figure 1: Albugo candida - symptoms of systemic infection (A), white rust symptoms on stem (B), swollen, malformed and steril flowers (C), sporangiospores (D)
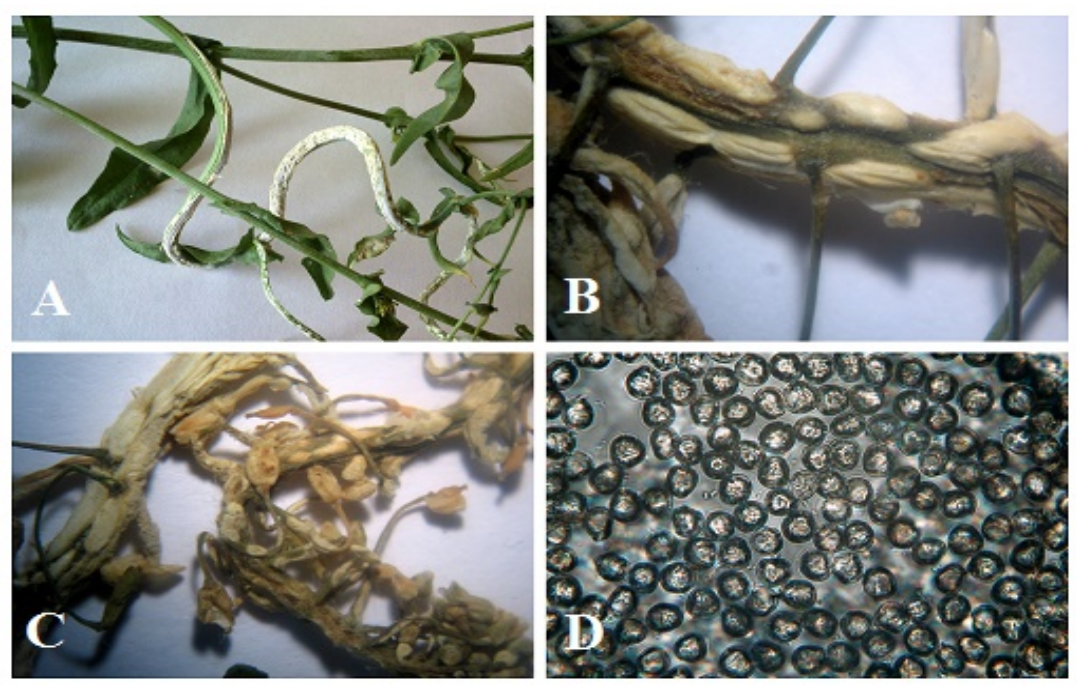

\section{Wilsoniana portulacae (DC.) Thines on common purslane (Portulaca oleracea L.)}

The pathogen was isolated from common purslane (Portulaca oleracea L.). In Hungary the disease is present in almost every region, but the intensity differe from year to year. Symptoms of disease are the following: multiple white pustules on the upper leaf side (Figure 2/A, 2/B), few pustules can be observed on stems. On the back side of the leaves were some chlorotic lesions, which were mostly small and irregular. In case of systemic infection the plant internodes were shortened and the leaves became smaller than regular, and when heavy infection appeared, the infested leaves fallen. The specialised hyphae which produce asexual spores (sporangiospores) are not branched, short and simple. Sporangiospores are translucent, mostly oval, sometimes almost spherical (Figure 2/C). The average size of them 20.2 x $18.8 \mu \mathrm{m}$. Sexual spores (oospores) can be observed in large numbers, which are dark-brown coloured, globose and the size in average of 25 measurements is $49.7 \mu \mathrm{m}$ in diameter (Figure 2/D).

\section{Wilsoniana bliti (Biv.) Thines on redroot pigweed (Amaranthus retroflexus L.)}

The last discussed white rust disease in this paper is Wilsoniana bliti, a common pathogen in Hungary which can be observed in almost every year on redroot pigweed (Amaranthus retroflexus). The characteristic white coloured pustules were formed on the lower leaves (Figure 3/A). On the leaf surface there were small, irregular chlorotic lesions (yellow spots) in different sizes. The pustules were groupped in the most cases with average size of 1-3(4) mm in diameter. Depending on the weather conditions of the year the scattered pustules can appeare only in few number on the leaves, but the fungus can often spread from one plant to another. Heavily infected plants may be shortened, their leaves became smaller and pitted, hereby the whole biomass of the plant 

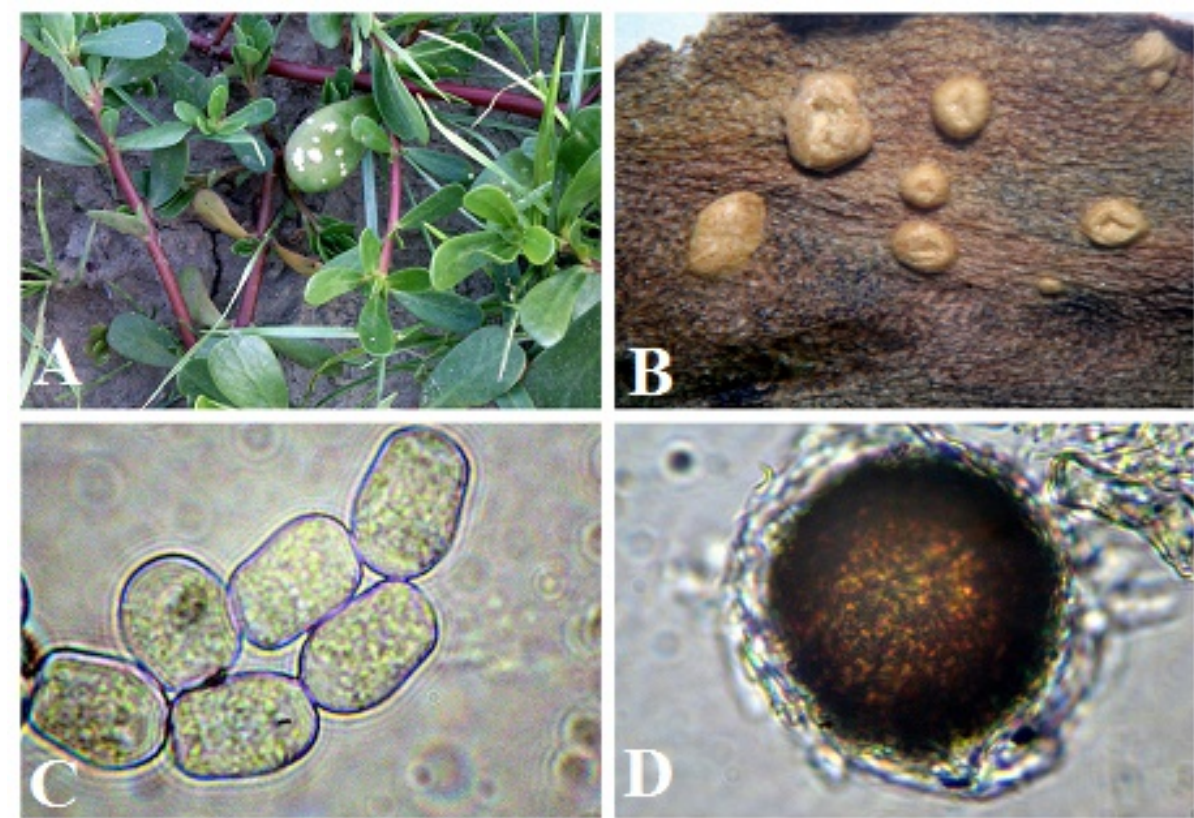

Figure 2: Wilsoniana portulacae - white pustules on the upper leaf side (A), small irregular enlarged pustules (B), translucent and oval sporangiospores (C), dark-brown, globose oospore (D)
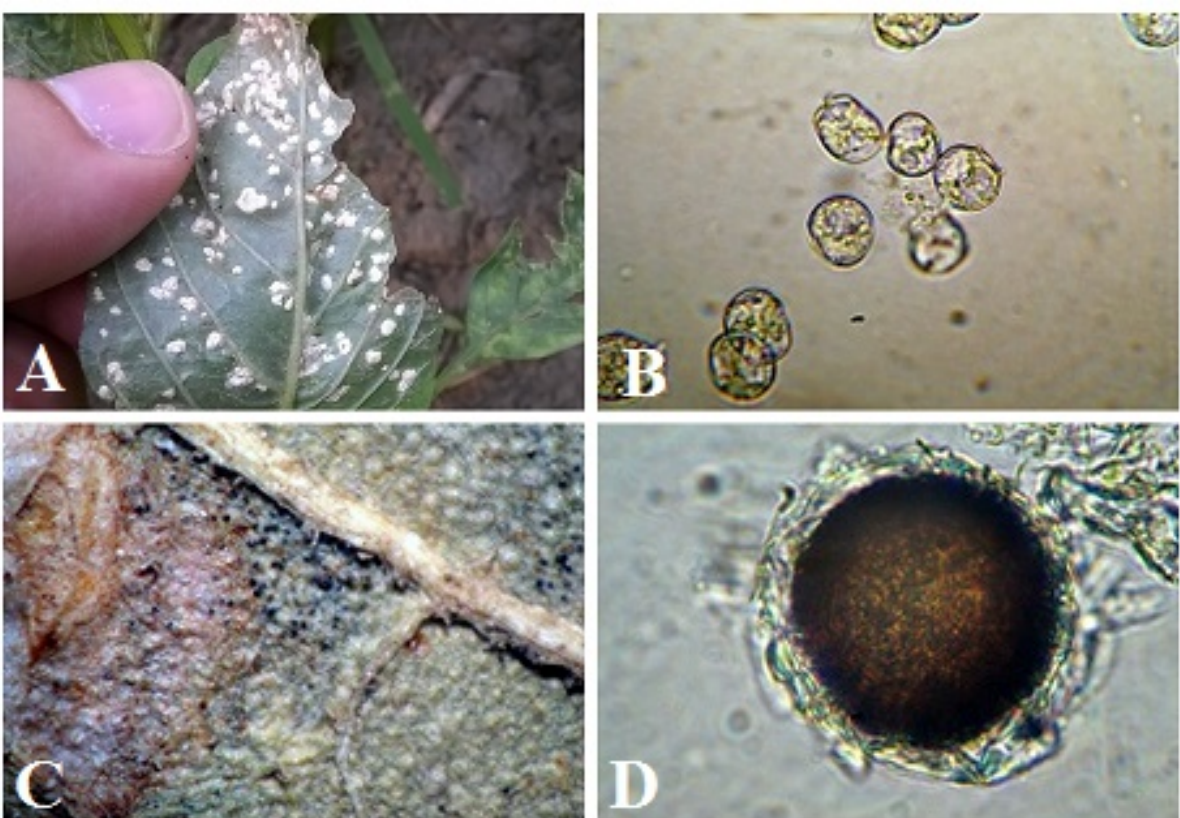

Figure 3:

Wilsoniana bliti - white pustules on the backside leaf (A), hyaline, oval sporangiospores (B), oospores near to the leaf vein (C), darkbrown, globose oospore (D)

decreased. In this fungus sporangiospores were also hyaline and oval to spherical (Figure 3/B), they formed in short and simple sporogenous hyphae. Average size of the asexual spores were $19.3 \times 16,1 \mu$. Numerous oospores were observed. This sexual spores mostly occured close to the leaf veins (Figure $3 / C$ ).

This structures were formed within the leaves, also were globose and dark-brown coloured (Figure 3/D). Once in a while the oospores may formed as a net-like structure on the lower leaves. The average measured size was $52.3 \mu \mathrm{m}$ in diameter.

\section{REFERENCES}

Biga, M.L.B. (1955): Riesaminazione delle specie del genre Albugo in base alla morfologia dei conidi. Sydowia 9: 339-358.

Choi, D. and Priest, M.J. (1995): A key to the genus Albugo. Mycotaxon 53: 261-272.

Choi, Y.-J. - Shin, H.-D. - Hong, S.-B. - Thines, M. (2007): Morphological and molecular discrimination among Albugo candida materials infecting Capsella bursa-pastoris worldwide. Fungal Diversity 27: 11-34.

Davis BM. (1904): The relationships of sexual organs in plants. Bot Gazette 38: 241-264. p. 
Farr, D.F. and Rossman, A.Y. (2015): Fungal Databases, Systematic Mycology and Microbiology Laboratory, ARS, USDA. Retrieved September 22, 2015, from http://nt.ars-grin.gov/fungaldatabases/

Gmelin, J.F. (1792): Caroli a Linné, Systema Naturae per Regna Tria Naturae, Secundum Classes, Ordines, Genera, Species, cum Characteribus, Differentiis, Synonymis, Locis, 2.

Persoon, C.H. (1801): Synopsis methodica fungorum. Göttingen.

Roussel, H.F.A. de (1806): Flore du Calvados. 2nd ed. Caen.

Thines, M. and Spring, O. (2005): A revision of Albugo (Chromista, Peronosporomycetes). Mycotaxon 92: 443-458. 